\title{
Oxidative balance in macroalgae from Antarctic waters. Possible role of Fe
}

\author{
Paula Mariela González a,1, Dolores Deregibus ${ }^{\text {b, } 1}$, Gabriela Malanga a , Gabriela Laura Campana ${ }^{\text {b,c }}$, \\ Katharina Zacher ${ }^{\mathrm{d}}$, María Liliana Quartino ${ }^{\mathrm{b}, \mathrm{e}}$, Susana Puntarulo ${ }^{\mathrm{a}, *}$

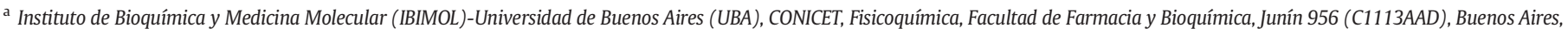 \\ Argentina \\ b Instituto Antártico Argentino, 25 de Mayo 1143, San Martin (CP1650), Buenos Aires, Argentina \\ c Universidad Nacional de Luján, R5 y Av. Constitución (CP6700), Luján, Buenos Aires, Argentina \\ d Alfred Wegener Institute Helmholtz Centre for Polar and Marine Research, Am Handelshafen 12, D-27570 Bremerhaven, Germany \\ e Museo Argentino de Ciencias Naturales "B. Rivadavia”, Av. A. Gallardo 470 (C1405DJR), Buenos Aires, Argentina
}

\section{A R T I C L E I N F O}

\section{Article history:}

Received 1 June 2016

Received in revised form 18 October 2016

Accepted 19 October 2016

Available online xxxx

\section{Keywords:}

Antarctica

Antioxidants

$\mathrm{Fe}$

Lipid radicals

Macroalgae

Oxidative stress

\begin{abstract}
A B S T R A C T
The hypothesis of this work was that exposure to diverse abiotic factors in two sites with different sediment and iron input (Peñón de Pesca: low impact; Island D: high impact, both areas in Potter Cove, King George Island, Antarctica) affects the physiological and oxidative profile of Gigartina skottsbergii and Himantothallus grandifolius. Daily metabolic carbon balance was significantly lower in both macroalgae from Island D compared to Peñón de Pesca. Lipid radical (LR•) content was significantly higher in G. skottsbergii collected from Island D compared to Peñón de Pesca. In contrast, $H$. grandifolius showed significantly lower values in Island D compared to Peñón de Pesca. The $\beta$-carotene $(\beta-C)$ content was significantly lower in G. skottsbergii from Island D compared to Peñón de Pesca, and the ratio $L R \bullet / \beta-C$ showed a 6 -fold increase in Island D samples compared to Peñón de Pesca. On the other hand, $\beta-C$ content in $\mathrm{H}$. grandifolius showed no significant differences between both areas. The LR•/B-C content ratio in this alga was significantly lower (26\%) in Island D as compared to Peñón de Pesca. Total iron content was significantly higher in both macroalgae from Island D compared to samples from Peñón de Pesca. Results with G. skottsbergii suggested changes in the oxidative cellular balance, probably related to the higher environmental iron in Island D as compared to Peñón de Pesca. The species H. grandifolius seems to be better adapted to the environmental conditions especially through a higher antioxidant capacity to cope with oxidative stress.
\end{abstract}

(C) 2016 Elsevier B.V. All rights reserved.

\section{Introduction}

Extreme seasonal variations in light regime, low temperatures, and extended periods of ice cover and snow characterize the Polar Regions (Wiencke et al., 2007). Particularly over the West Antarctic Peninsula, glacial retreat has increased over the last decades due to global warming (Rückamp et al., 2011) impacting on benthic ecosystems (Gutt et al.,

Abbreviations: $\mathrm{AH}^{-}$, ascorbate; $\beta-\mathrm{C}, \beta$-carotene; CAT, catalase; Chl- $a$, chlorophyll- $a$; EPR, electron paramagnetic resonance; GST, glutathione-S-transferase; LR•, lipid radicals; $\mathrm{P}_{\max }$, net photosynthesis; PAR, photosynthetically active radiation; POBN, $\alpha$-(4-pyridyl 1-oxide)- $N$-t-butyl nitrone; ROS, reactive oxygen species; SOD, superoxide dismutase; $\alpha$-T, $\alpha$-tocopherol; TEMPOL, 4-hydroxy-2,2,6,6-tetramethylpiperidinyloxy.

* Corresponding author at: Fisicoquímica-IBIMOL, Facultad de Farmacia y Bioquímica, Junín, 956 (C1113AAD), Buenos Aires, Argentina.

E-mail addresses: paulag@ffyb.uba.ar (P.M. González), dderegibus@dna.gov.ar (D. Deregibus),gmalanga@ffyb.uba.ar (G. Malanga),gcampana@dna.gov.ar (G.L. Campana), katharina.zacher@awi.de (K. Zacher), lquartino@dna.gov.ar (M.L. Quartino), susanap@ffyb.uba.ar (S. Puntarulo).

1 Equal contribution to the manuscript.
2015). Meltwater increments from glaciers due to global warming have substantial effects on light penetration, salinity, temperature, nutrient conditions and metal inputs due to higher sediment run-off in coastal waters (Dierssen et al., 2002; Quartino et al., 2013; Sahade et al., 2015). In the King George Island region, Antarctica, high sedimentation reduces underwater photosynthetically active radiation (PAR, 400$700 \mathrm{~nm}$ ) leading to a lower carbon balance by some macroalgal species (Deregibus et al., 2016). Furthermore, the sediment and rocks in this island are rich in iron (Fe), containing 5 to $7 \%$ Fe (Tatur et al., 1999), and thus sediment ablation enriches the seawater in Fe (Ahn et al., 1996; Dierssen et al., 2002). In biological systems, Fe is an essential micronutrient for cellular functioning and growth (Templeton and Liu, 2003). It is also involved in several biochemical reactions that lead to deleterious effects through its catalytic activity. $\mathrm{Fe}^{2+}$ catalyzes the reduction of $\mathrm{H}_{2} \mathrm{O}_{2}$ generating the extremely reactive hydroxyl radical $(\bullet \mathrm{OH})$ (Fenton and Haber-Weiss reactions). In this way, Fe catalyzes the conversion of normal cell respiration by-products into highly cell damaging radical species. 
The effects of heavy metal excess on algae include cell lysis, growth inhibition, reduced photosynthesis, disrupted calcification, disturbances in sexual reproduction, induction of the production of reactive oxygen species (ROS) and imbalance of the cellular oxidative status (Collén et al., 2003). Reactions involving ROS are responsible for alterations in the fluidity, integrity, permeability, and function of membranes that include the disturbance of ion-gradients and impairment of lipid-protein interactions naturally occurring within the cells (Halliwell and Gutteridge, 1989). Moreover, lipids are critical targets for the action of ROS, generating lipid radicals (LR•) among other cellular sub-products. In spite of the activity of the antioxidant systems (enzymatic and nonenzymatic) that regulate oxidative stress and damage, living cells could be overwhelmed by endogenous and/or exogenous oxidative challenges from the environment (Chow, 1988). As a response to the exposure to potentially damaging factors, algae could increase the activity of enzymatic antioxidants (e.g. catalase, CAT; superoxide dismutase, SOD and glutathione-S-transferase, GST) and the content of both water and lipid soluble antioxidants (e.g. ascorbate, $\mathrm{AH}^{-} ; \alpha$-tocopherol, $\alpha$-T and $\beta$-carotene, $\beta-C$ ). Among them, $\alpha$-T and $\beta-C$ have the ability to protect polyunsaturated fatty acids from peroxidation and to scavenge free radicals (Evstigneeva et al., 1998). González et al. (2013) proposed the use of indexes such as $\mathrm{LR} \bullet / \alpha-\mathrm{T}$ and/or $\mathrm{LR} \bullet / \beta-C$, as sensitive indicators of oxidative stress in the lipophilic media in marine organisms, since oxidative stress-dependent effects reflect the imbalance between oxidative damaging species and protection in the internal cellular environment. Moreover, red algae from both polar regions have been shown to produce mycosporine-like amino acids as photoprotective substances (Aguilera et al., 2002), and some Antarctic brown algae (Fairhead et al., 2005) contain phlorotannins that are a class of polyphenolic compounds that shows remarkable bioactivities such as antioxidant properties (Li et al., 2009).

Antarctic macroalgae colonize nearshore areas with hard substrates (e.g. rocks and boulders), and occur in distinct vertical zonation mainly between the intertidal and the subtidal zone down to $30 \mathrm{~m}$ depth (Wiencke and Clayton, 2002). The red alga Gigartina skottsbergii, Setchell and Gardner 1936, is a subtidal species that occurs in the Antarctic Peninsula, the South Shetland Islands and the South Orkney Islands (Billard et al., 2015). It is morphologically similar to the algae named G. skottsbergii from South America, but probably represents a separate species (Billard et al., 2015; Hommersand et al., 2009). It is a pseudoperennial macroalga whose blades may reach up to $60 \mathrm{~cm}$ or more (Wiencke and Clayton, 2002). The brown macroalga Himantothallus grandifolius (Gepp and Gepp) Zinova 1959, inhabiting Antarctic waters, is the largest Antarctic seaweed (up to $10 \mathrm{~m}$ thallus length). Whereas G. skottsbergii occurs predominantly in shallow waters, $H$. grandifolius mostly occurs in deeper waters on vertical rocks and boulders in conditions of moderate to low turbulence and on less stable substrata, such as pebbles and gravels (Wiencke et al., 2007). Both species have completely different life strategies. While G. skottsbergii is a typical opportunistic species known as a seasonal responder that reacts mainly to environmental conditions and grows in the Antarctic summer, $H$. grandifolius is a seasonal anticipator that grows in late winter/spring based on photoperiodic and circannual rhythms using stored carbon (Wiencke and Amsler, 2012). Moreover, they belong to two algal divisions highly divergent in terms of phylogeny, depth distribution, morpho-functional attributes and ecological functions. The different life strategies may also influence the antioxidant responses of both species.

The hypothesis of this work was that the exposure to diverse abiotic factors, as a consequence of the glacier impact, affects the physiological and oxidative profiles of both G. skottsbergii and H. grandifolius. Since higher sediment load, which implies less light and higher Fe values, is present in Island D compared to Peñón de Pesca, Potter Cove, King George Island, Antarctica, algae present in Island D could be more affected than in Peñón de Pesca. The main objective was to analyze photophysiological parameters (Chlorophyll $a$, Chl-a, content, photosynthetic efficiency, saturation and compensation points, respiration and daily metabolic carbon balance) and the oxidative profile (LR・ content and antioxidants) of the two macroalgae living in Antarctic waters ( $G$. skottsbergii and $H$. grandifolius), in different areas. The putative development of adaptive factors was analyzed.

\section{Materials and methods}

\subsection{Study area}

The study was conducted at Potter Cove $\left(62^{\circ} 14^{\prime} \mathrm{S}, 58^{\circ} 38^{\prime} \mathrm{W}\right.$, King George Island/Isla 25 de Mayo, South Shetland Islands, Antarctica) in two different areas (Peñón de Pesca and Island D) at the north-east side of the cove. These two sites were chosen due to their different positions and abiotic characteristics. Peñón de Pesca (S 62 ${ }^{\circ} 14^{\prime} 21^{\prime \prime}$; W $\left.58^{\circ} 42^{\prime} 91^{\prime \prime}\right)$ is located outside the cove far from the retreating glacier, where the clear water of Maxwell Bay penetrates clockwise; while Island D (S 62 $13^{\prime} 25.9^{\prime \prime}$; W $\left.58^{\circ} 38^{\prime} 38.2^{\prime \prime}\right)$ is a rocky island at the inner end of the cove near the glacier, heavily influenced by sediment inflow, which appeared approximately in 2003 following deglaciation (Fig. 1; supplementary maps available at Deregibus et al., 2015, http://dx.doi. org/10.1594/PANGAEA.853859).

\subsection{Quantum irradiance, salinity and temperature measurements}

Underwater photosynthetically active radiation (PAR, 400-700 nm) was recorded every 15 min over 7 (seven) consecutive days during sampling at $5 \mathrm{~m}$ depth in each area. Measurements were performed using an Odyssey Photosynthetic Irradiance Recording System (Data Flow Systems, Christchurch, New Zealand). Light meters were calibrated 7 (seven) days prior to deployment against a LI-COR LI 1400 datalogger equipped with a LI-COR 190 PAR sensor (Deregibus et al., 2016). After calibration, light loggers were positioned standing upright on tripods and secured by SCUBA divers. During the same period, salinity (PSU) and water temperature $\left({ }^{\circ} \mathrm{C}\right.$ ) were measured using a CTD (SeaBird, SBE19plus, USA) in each area.

\subsection{Algal collection and maintenance}

Three adult individuals of $H$. grandifolius and G. skottsbergii were collected at $5 \mathrm{~m}$ water depth in both areas by SCUBA diving during summer 2011-2012. All individuals were covered by dark plastic bags and kept in aerated $0{ }^{\circ} \mathrm{C}$ seawater from the cove in a culture room. Subsequently, algal pieces of approximately $0.5 \mathrm{~g}$ were cut from the middle part of the lamina, between the distal and the basal parts, and kept overnight in the dark in filtered seawater at $0^{\circ} \mathrm{C}$ to avoid wounding effects (Drew, 1983). The algal pieces were stored at $-70{ }^{\circ} \mathrm{C}$ until used for measurement of oxidative parameters.

\subsection{Content of Chl-a}

Extraction of Chl- $a$ was carried out using $N, N$-dimethyl formamide, as described by Inskeep and Bloom (1985). Optical density was measured in a spectrophotometer (Pharmacia Biotech Ultrospec 3000, Cambridge, England) at $\lambda=664 \mathrm{~nm}$, and the Chl- $a$ content was calculated according to Inskeep and Bloom (1985).

\subsection{Photosynthetic measurements and quantification of the daily metabolic carbon balance}

Photosynthesis and dark respiration were measured in a constantly stirred plastic chamber $(30 \mathrm{~mL})$ fitted with a fiber-optic $\mathrm{O}_{2}$ mini sensor, connected to an OXY-4 (4 channel Fiber Optic Oxygen Meter, PreSens, Regensburg, Germany). The chamber was placed in a water bath kept at constant temperature $\left(2.00 \pm 0.01{ }^{\circ} \mathrm{C}\right)$ with a thermostat (Haake DC3, Karlsruhe, Germany). A slide projector (Leica, Pradovit CA2502, 


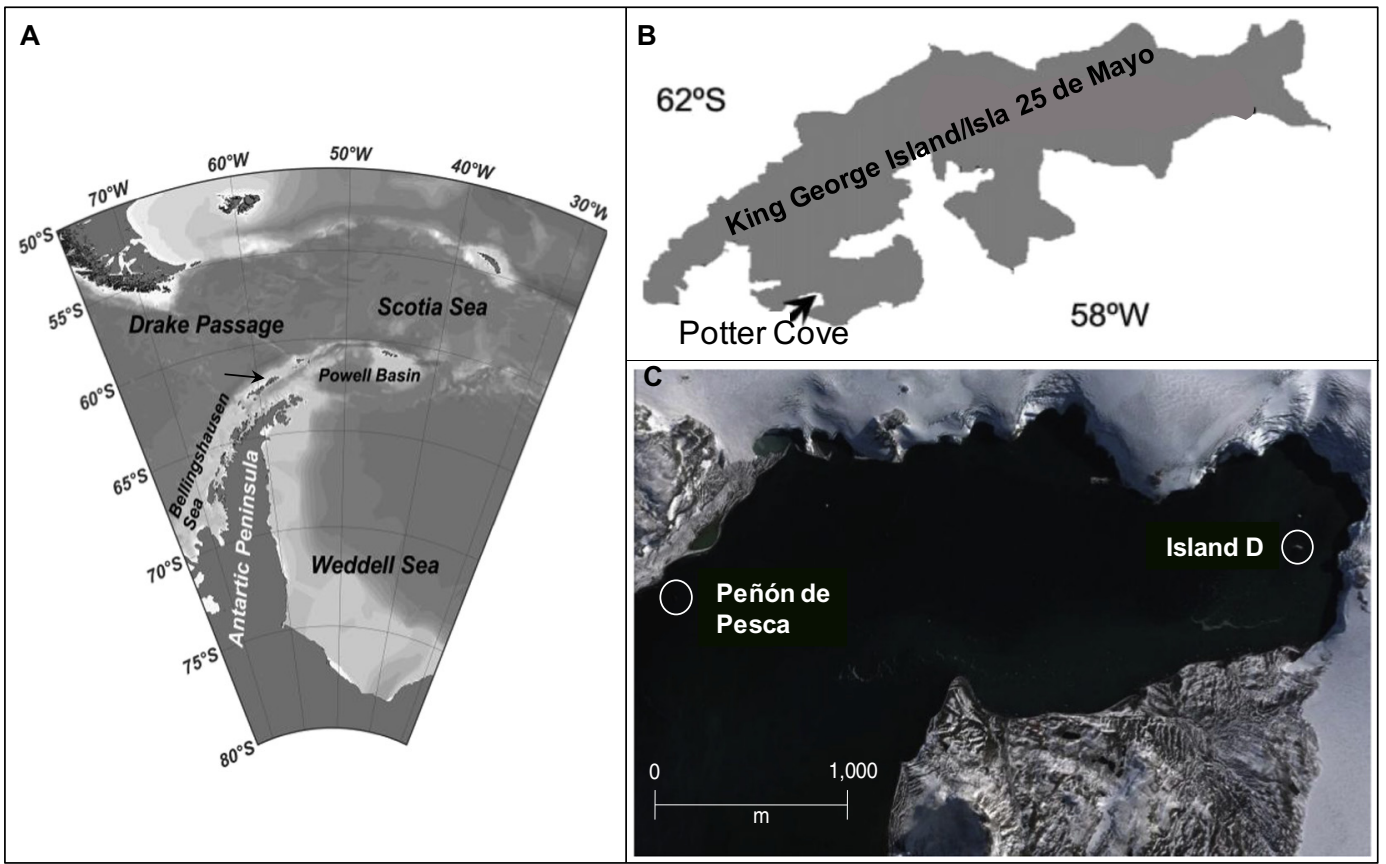

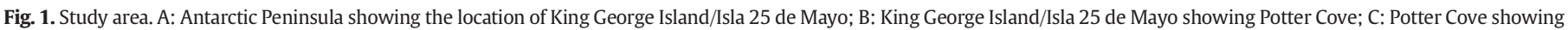
the 2 (two) different sampled areas, Peñón de Pesca and Island D.

Frankfurt, Germany) was used as the light source. Different glass filters (Schott, Mainz, Germany) were used to obtain distinct light amounts measured with a LI-COR LI 1400 datalogger equipped with a LI-COR sensor 192SA (LI-COR, Lincoln, USA). Four equal set-ups were installed and three replicates of each species were measured simultaneously. The dark respiration rate was measured for $20 \mathrm{~min}$, followed by 8 different photon fluence rates increasing from 1 to $800 \mu \mathrm{mol}$ photons $\mathrm{m}^{-2} \mathrm{~s}^{-1}$ ( $\pm 20 \mu \mathrm{mol}$ photon $\mathrm{m}^{-2} \mathrm{~s}^{-1}$ in the three replicates) to measure $\mathrm{O}_{2}$ production during a period of $10 \mathrm{~min}$ for each photon fluence rate. Photosynthesis vs. irradiance curves were obtained and used to calculate photosynthetic parameters ( $\mathrm{P}_{\max }$, which is the maximum photosynthetic rate; the photosynthetic efficiency, which is the initial slope of the curve at low irradiance; the saturation point, which is the light saturation point of photosynthesis; the light compensation point, and the respiration, which is the dark respiration rate) as described by Deregibus et al. (2016). The continuous PAR data ( $\mu \mathrm{mol}$ photons $\mathrm{m}^{-2} \mathrm{~s}^{-1}$ ) were plotted against time of the day (every $15 \mathrm{~min}$ ) at $5 \mathrm{~m}$ depth for Peñón de Pesca and Island D. Calculations of daily net carbon balance ( $\mathrm{mg} \mathrm{C} \mathrm{g} \mathrm{FW}^{-1} \mathrm{~d}^{-1}$ ) were performed by using the obtained photosynthetic parameters and incident irradiances as described by Deregibus et al. (2016).

\subsection{Content of $L R \bullet$}

Macroalgae homogenates were prepared in potassium phosphate buffer ( $\mathrm{pH} 7.4$ ) containing $130 \mathrm{mM}$ of the spin trap $\alpha$-(4-pyridyl 1oxide)- $\mathrm{N}$-t-butyl nitrone (POBN, Sigma-Aldrich, St. Louis, MO, USA). Electron Paramagnetic Resonance (EPR) spectra were measured using a Bruker (Karlsruhe, Germany) spectrometer ECS 106 with a ER 4102ST cavity, operating with the following instrument settings: room temperature $\left(18{ }^{\circ} \mathrm{C}\right), 9.81 \mathrm{GHz}$ microwave frequency, $22.6 \mathrm{~mW}$ microwave power, $50 \mathrm{kHz}$ modulation frequency, $1.232 \mathrm{G}$ modulation amplitude, $81.92 \mathrm{~ms}$ time constant and $2 \times 10^{4}$ receiver gain (Jurkiewicz and Buettner, 1994). Quantification of the spin adduct was performed using an aqueous solution of 4-hydroxy-2,2,6,6-tetramethyl piperidinyl oxy (TEMPOL) introduced into the same sample cell used for the samples. The EPR spectra of the samples and TEMPOL solutions were recorded at exactly the same spectrometer settings and the first derivative EPR spectra were double integrated to obtain the area intensity, from which the concentration of the radical was calculated according to Kotake et al. (1996).

\subsection{Enzymatic antioxidant activities}

Homogenates from G. skottsbergii in a 1:18 (w/v) ratio and $H$. grandifolius in a $1: 9(\mathrm{w} / \mathrm{v})$ ratio were prepared in $50 \mathrm{mM}$ potassium phosphate- $120 \mathrm{mM} \mathrm{KCl}(\mathrm{pH}=7.4)$ and centrifuged at $600 \mathrm{~g}$ for 10 min at $4{ }^{\circ} \mathrm{C}$. The CAT activity was determined spectrophotometrically by the decomposition of $\mathrm{H}_{2} \mathrm{O}_{2}$ (Sigma-Aldrich, St. Louis, MO, USA) at $\lambda=240 \mathrm{~nm}$ at $20^{\circ} \mathrm{C}$, according to Aebi (1984). The SOD activity was determined based on its capacity to inhibit the reduction of cytochrome $c$ by superoxide radicals generated by the xanthine-xanthine oxidase system. One unit of SOD was defined as the amount of enzyme able to inhibit the cytochrome $c$ reduction rate by $50 \%$ (McCord and Fridovich, 1969). The GST activity was determined by measuring the increase in absorbance at $\lambda=340 \mathrm{~nm}$ and incubating reduced glutathione and 1chloro-2.4-dinithrobenzene (Sigma-Aldrich, St. Louis, MO, USA) as substrates according to Habig et al. (1974). Protein content was calculated according to Bradford (1976).

\subsection{Content of non-enzymatic antioxidants}

The $\mathrm{AH}^{-}$content was measured by reverse-phase HPLC with electrochemical detection. Samples were homogenized in a 5:1 $(\mathrm{w} / \mathrm{v})$ ratio in metaphosphoric acid $10 \%(w / v)$ according to Kutnink et al. (1987). Commercially available $\mathrm{AH}^{-}$was used as standard (Sigma-Aldrich, St. Louis, MO, USA). The content of $\alpha-T$ and $\beta-C$ in the homogenates (60 mg $615 \mu \mathrm{L}^{-1}$ of water, $0.1 \mathrm{M}$ sodium dodecyl sulfate and $4 \%$ $(\mathrm{w} / \mathrm{v})$ butylated hydroxytoluene) were quantified by reverse-phase HPLC with electrochemical detection using a Bioanalytical Systems LC4C amperometric detector with a glassy carbon working electrode at an applied oxidation potential of $+0.6 \mathrm{~V}$ (Malanga and Puntarulo, 1995). Extraction from the samples was performed with $600 \mu \mathrm{L}$ methanol and $1 \mathrm{~mL}$ hexane. After centrifugation at $2300 \mathrm{~g}$ for $5 \mathrm{~min}$, the hexane phase was removed and evaporated to dryness under $\mathrm{N}_{2}$. Extracts were dissolved in methanol:ethanol $(1: 1 \mathrm{v} / \mathrm{v})$ and injected for HPLC analysis. 
The HPLC measurement conditions were: isocratic reversed phase; column: Supelcosil LC-8; $15 \mathrm{~cm} \times 4.6 \mathrm{~cm} \times 3 \mu \mathrm{m}$; mobile phase: $20 \mathrm{mM}$ lithium perclorate in methanol/water $99 / 1(\mathrm{v} / \mathrm{v})$, flow rate:

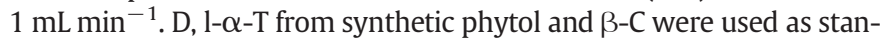
dards (Sigma-Aldrich, St. Louis, MO, USA).

\subsection{Total Fe content}

Macroalgae samples were mineralized employing a muffle. A sequence of temperatures was applied up to $500^{\circ} \mathrm{C}$, with $100^{\circ} \mathrm{C}$ increases, by $30 \mathrm{~min}$ (Du Laing et al., 2003). The Fe concentration in the digests was measured spectrophotometrically at $\lambda=535 \mathrm{~nm}$ after reduction with thioglycolic acid (Sigma-Aldrich, St. Louis, MO, USA) followed by the addition of bathophenanthroline (Sigma-Aldrich, St. Louis, MO, USA) (Brumby and Massey, 1967).

\subsection{Statistical analyses}

Data in the text and tables are expressed as mean \pm S.E.M. of 3 (three) specimens per site and per species, with 3 (three) replicates of the same macroalgae in each experiment. A General Linear Model (ANOVA) was performed to test for the effects of the area on light, salinity, temperature and photosynthetic parameters in each species. In addition, photosynthetic parameters were compared between the 2 (two) studied species in each area and between areas. Homogeneity of variances was checked using Cochran's Test and post hoc multiple means comparisons were analyzed using DGC Test with Infostat 2008 software package (Di Rienzo et al., 2008). Statistical tests for stress parameters (ANOVA) were carried out using Statview for Windows, (SAS Institute Inc., version 5.0).

\section{Results}

Environmental conditions were characterized in Peñón de Pesca and Island $\mathrm{D}$ by assessing irradiance, salinity and temperature (Table 1 ). Neither salinity nor temperature were significantly different between areas but strongly lower irradiance values were measured in Island D compared to Peñón de Pesca.

For G. skottsbergii neither photosynthetic efficiency $(0.03 \pm 0.02$ and $0.07 \pm 0.03 \mu \mathrm{mol} \mathrm{O}_{2} \mathrm{~m}^{2} \mu \mathrm{mol}$ photons ${ }^{-1} \mathrm{~g} \mathrm{FW}^{-1}$ in Peñón de Pesca and Island $\mathrm{D}$, respectively), nor saturation point (30 \pm 19 and $21 \pm$ $10 \mu \mathrm{mol}$ photons $\mathrm{m}^{-2} \mathrm{~s}^{-1}$ in Peñón de Pesca and Island $\mathrm{D}$, respectively), nor the compensation point $\left(16 \pm 10\right.$ and $15 \pm 6 \mu$ mol photons $\mathrm{m}^{-2} \mathrm{~s}^{-1}$ in Peñón de Pesca and Island D, respectively) showed any significant differences between areas. Moreover, no significant differences in net photosynthesis $\left(\mathrm{P}_{\max }\right)$ values $\left(31.6 \pm 0.6\right.$ and $41 \pm 7 \mu \mathrm{mol} \mathrm{O}_{2} \mathrm{~g} \mathrm{FW}^{-1} \mathrm{~h}^{-1}$ in Peñón de Pesca and Island $\mathrm{D}$, respectively) and respiration rates $\left(15.4 \pm 0.4\right.$ and $28 \pm 5 \mu \mathrm{mol} \mathrm{O}_{2} \mathrm{~g} \mathrm{FW}^{-1} \mathrm{~h}^{-1}$ in Peñón de Pesca and Island $\mathrm{D}$, respectively) were observed in the analyzed samples. Nevertheless, Chl- $a$ content and daily metabolic carbon balance were significantly lower in specimens taken from Island D as compared to those collected from Peñón de Pesca (Fig. 2).

The combination of LR with the spin trap POBN resulted in adducts that gave a characteristic EPR spectrum with hyperfine coupling constants of $\mathrm{a}_{\mathrm{N}}=15.8 \mathrm{G}$ and $\mathrm{a}_{\mathrm{H}}=2.6 \mathrm{G}$ in homogenates from samples of

Table 1

Environmental parameters.

\begin{tabular}{lll}
\hline & \multicolumn{2}{c}{ Area } \\
\cline { 2 - 3 } \cline { 2 - 3 } & Peñón de Pesca & Island $\mathrm{D}$ \\
\hline Irradiance $\left(\mu \mathrm{mol}\right.$ photons $\left.\mathrm{m}^{-2} \mathrm{~s}^{-1}\right)$ & $230 \pm 49$ & $57 \pm 26^{*}$ \\
Salinity $(\mathrm{psu})$ & $34.0 \pm 0.1$ & $33.7 \pm 0.2$ \\
Temperature $\left({ }^{\circ} \mathrm{C}\right)$ & $1.2 \pm 0.4$ & $0.9 \pm 0.4$ \\
\hline
\end{tabular}

* Significantly different from values obtained in specimens collected from Peñón de Pesca (ANOVA, $\mathrm{p}<0.05$ ).

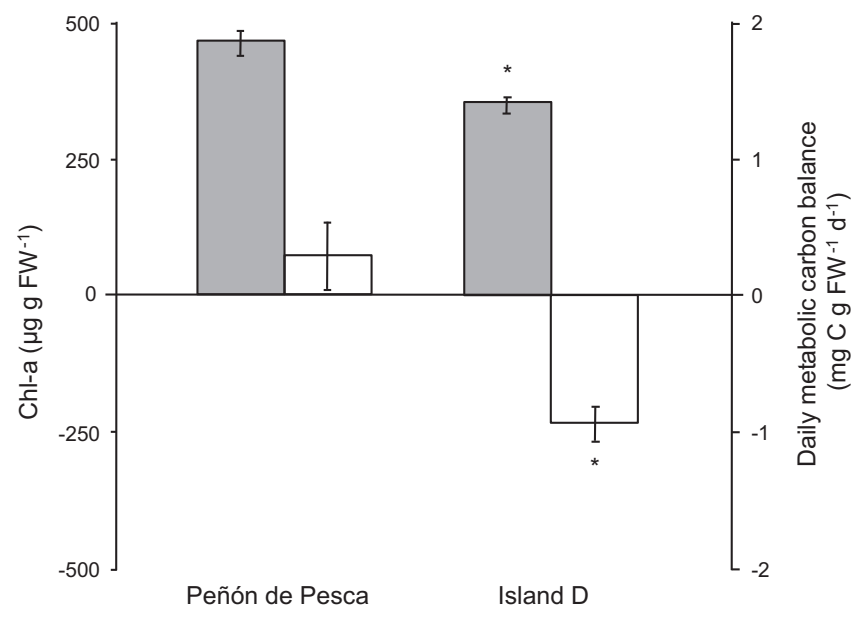

Fig. 2. Chl- $a$ content ( $\square$ ) and daily metabolic carbon balance ( $\square$ ) in G. skottsbergii collected from 2 (two) different areas at Potter Cove. Continuous PAR 24 h data approximated and obtained during 2011-2012. Daily metabolic carbon balance values correspond to an overall net gain or loss of $C$ during 24 h. *Significantly different from Peñón de Pesca. ANOVA, $\mathrm{p}<0.05$.

G. skottsbergii, collected from both Peñón de Pesca and Island D, in agreement with computer simulated signals obtained using those parameters (Fig. 3A a). The POBN solution was tested and no POBN spin adducts were observed (Fig. 3A d). Quantification of the LR•-dependent EPR signals showed that LR• content was significantly higher in macroalgae that inhabit the Island D zone, as compared to samples isolated from specimens collected in Peñón de Pesca (Fig. 3B).

Regarding the activity of the antioxidant enzymes in G. skottsbergii collected from Island D, a significantly higher activity was measured for CAT and GST (Table 2) as compared to those values in algae collected in Peñón de Pesca. The SOD activity and the content of $\alpha$-T showed no significant differences in the organisms in both locations, and the content of $\mathrm{AH}^{-}$and $\mathrm{B}-\mathrm{C}$ was lower in the macroalgae collected from Island $\mathrm{D}$ as compared to the values measured in Peñón de Pesca (Table 2).

$\mathrm{The} \mathrm{LR} \bullet / \alpha-\mathrm{T}, \mathrm{LR} \bullet / \beta-\mathrm{C}$ and $\mathrm{LR} \bullet /(\alpha-\mathrm{T}+\beta-\mathrm{C})$ content ratios were increased by 2-, 6- and 4-fold, respectively in G. skottsbergii collected from Island D, as compared to the values measured in samples isolated from specimens taken from Peñón de Pesca (Fig. 4), suggesting that damage overwhelmed protection in macroalgae from Island D as compared to samples from Peñón de Pesca.

Due to the known role of Fe as catalyzer of reactive species generation, total Fe content in macroalgae was assessed. Data in Table 3 show that the Fe content was significantly different in the macroalgae G. skottsbergii collected in Island D as compared to Peñón de Pesca.

The same set of analyses were assessed for $H$. grandifolius (Table 4). Photosynthetic efficiency, saturation and compensation point, $\mathrm{P}_{\max }$ values, and respiration rates, showed no significant differences between specimens collected in both areas. On the other hand, in agreement with the data taken for $G$. skottsbergii, only daily metabolic carbon balance and Chl- $a$ content showed significant differences between areas. In $H$. grandifolius Chl- $a$ content was significantly higher in algae obtained from Island D as compared to organisms from Peñón de Pesca.

Regarding the activities of the antioxidant enzymes in $H$. grandifolius, the CAT activity showed no significant differences between areas. In contrast, the SOD activity was significantly lower and the GST activity was significantly higher in macroalgae from Island D as compared to samples collected in Peñón de Pesca (Table 5). On the other hand, both the $\alpha$-T and $\beta$-C content showed no significant differences in samples collected in both locations, but $\mathrm{AH}^{-}$content was significantly lower in macroalgae from Island D as compared to those obtained from Peñón de Pesca (Table 5).

Samples of $H$. grandifolius showed significantly lower values of LR content in the macroalgae collected in Island D as compared to those 
A

a
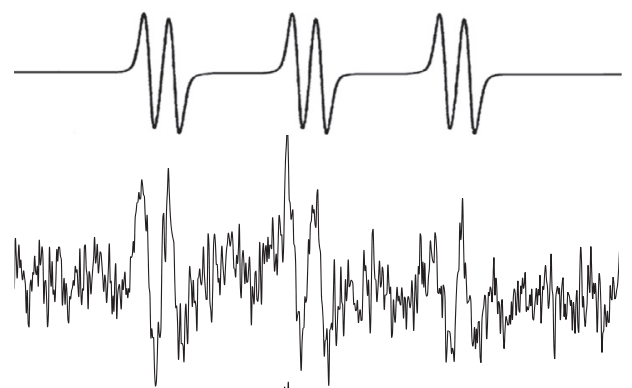

C<smiles>[AlH2]</smiles>

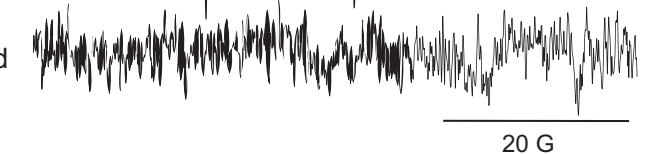

B

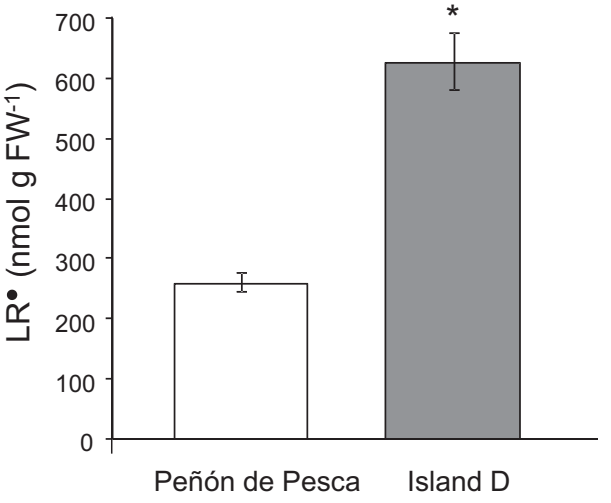

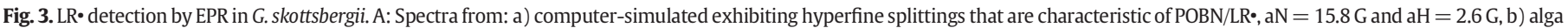

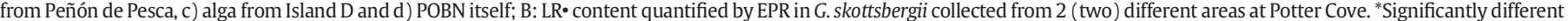
from Peñón de Pesca. ANOVA, $\mathrm{p}<0.0001$.

specimens taken from Peñón de Pesca, and the $\mathrm{LR} \bullet / \alpha-\mathrm{T}, \mathrm{LR} \bullet / \beta-\mathrm{C}$ and $\mathrm{LR} \bullet /$ $(\alpha-T+\beta-C)$ content ratios were decreased in samples collected in Island D as compared to Peñón de Pesca (Table 6).

Moreover, Table 3 indicates that the total Fe content was significantly higher (1.9-fold) in the macroalgae $H$. grandifolius collected from Island D with respect to Peñón de Pesca.

\section{Discussion}

The studied macroalgae, G. skottsbergii and H. grandifolius, have different requirements for survival. Assuming that the daily metabolic carbon balance represents the balance between the metabolic carbon gained and lost, the data reported here showed that carbon losses were significantly higher than gains in both macroalgae species collected from Island D. Negative daily metabolic carbon balance values were measured in areas with high turbidity, such as Island D, and it was suggested that macroalgae might use their storage compounds to meet their metabolic needs (Drew and Hastings, 1992; Kirst and Wiencke, 1995; Wiencke and Amsler, 2012).

In the present study, the lower irradiance PAR values assessed in Island D compared to Peñón de Pesca are consistent with previous findings that have shown that the inflow of sediment during the warmer

Table 2

Activity of enzymatic and content of non-enzymatic antioxidants in G. skottsbergii.

\begin{tabular}{llll}
\hline & \multicolumn{2}{c}{ Area } & \\
\cline { 2 - 3 } & Peñón de Pesca & Island D & \\
\hline CAT $\left(\mathrm{pmol} \mathrm{g} \mathrm{FW}^{-1}\right)$ & $0.38 \pm 0.02$ & $0.61 \pm 0.08^{*}$ & $(+60 \%)$ \\
$\mathrm{SOD}\left(\mathrm{U} \mathrm{g} \mathrm{FW}^{-1}\right)$ & $410 \pm 90$ & $590 \pm 80$ & \\
$\mathrm{GST}$ & $13 \pm 2$ & $26 \pm 3^{* *}$ & $(+100 \%)$ \\
$\quad\left(\mathrm{M} \mathrm{min} \mathrm{g} \mathrm{FW}^{-1}\right)$ & & & \\
$\mathrm{AH}\left(\mathrm{gmol} \mathrm{g} \mathrm{FW}^{-1}\right)$ & $3.9 \pm 0.1$ & $2.8 \pm 0.4^{*}$ & $(-28 \%)$ \\
$\mathrm{a}-\mathrm{T}\left(\mathrm{nmol} \mathrm{g} \mathrm{FW}^{-1}\right)$ & $4 \pm 1$ & $4.4 \pm 0.3$ & \\
$\mathrm{~b}-\mathrm{C}\left(\mathrm{nmol} \mathrm{g} \mathrm{FW}^{-1}\right)$ & $18 \pm 2$ & $6.4 \pm 0.7^{* *}$ & $(-64 \%)$ \\
\hline
\end{tabular}

* Significantly different from values obtained in specimens collected from Peñón de Pesca (ANOVA, $\mathrm{p}<0.05$ )

** Significantly different from values obtained in specimens collected from Peñón de Pesca (ANOVA, $\mathrm{p}<0.01$ ) months leads to marked seasonal variations in turbidity (Deregibus et al., 2016). Algal growth is constrained during 2 (two) or 3 (three) months a year until the sediment enters the water column (Wiencke and Amsler, 2012). High concentrations of land runoff are produced during summer glacial melting seasons in Potter Cove (Eraso and Domínguez, 2007), especially in newly ice-free areas close to the glacial run-off (Island D, Quartino et al., 2013). An increase in sediment input can also have positive effects in reducing exposure to excessive ultraviolet radiation (280-400 nm), and current circulation and wind cause resuspension processes (Schloss et al., 2012). Seaweeds in Potter Cove are not only shade-adapted but can also cope with high PAR intensities in summer as they are not photoinhibited even under very high irradiances (Deregibus et al., 2016; Wiencke and Amsler, 2012). Quartino et al. (2013) reported the presence of both $G$. skottsbergii and $H$. grandifolius in areas with high sedimentation showing that survival and reproduction skills of these algae under such circumstances are successful. Nevertheless, a higher percentage of $H$. grandifolius was observed in Island D, while G. skottsbergii showed more coverage in Peñón de Pesca, suggesting differences in adaptation to the stressful conditions (Quartino et al., 2013).

The different irradiance regimes found in this study may be a critical factor for the differences found in the Chl- $a$ content between both

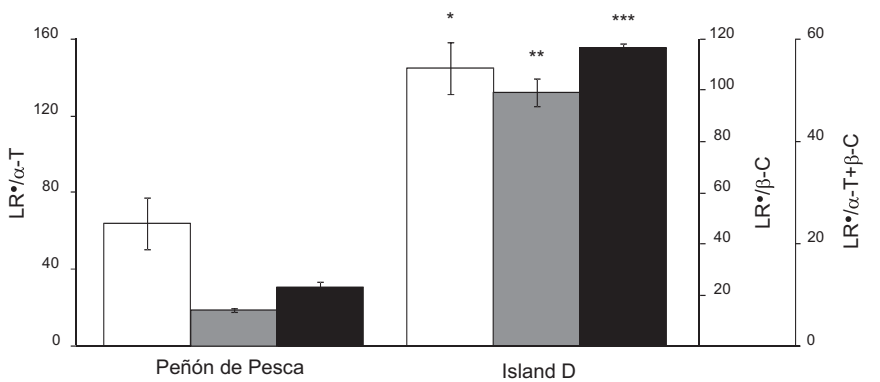

Fig. 4. Indexes of the damage/protection content ratio in G. skottsbergii collected from 2 (two) different areas at Potter Cove. LR $/ \alpha-\mathrm{T}(\square), \mathrm{LR} \bullet / \beta-\mathrm{C}(\square)$ and $\mathrm{LR} \bullet /(\alpha-\mathrm{T}+\beta-\mathrm{C})(\mathbf{\square})$ content ratio. *Significantly different from Peñón de Pesca. ANOVA, ${ }^{*} \mathrm{p}<0.05,{ }^{* *} \mathrm{p}<0.01$ and ${ }^{* * *} \mathrm{p}<0.001$. 
Table 3

Total Fe content in the studied areas and in the collected macroalgae.

\begin{tabular}{|c|c|c|c|}
\hline \multirow[t]{3}{*}{ Area } & \multicolumn{2}{|c|}{ Total Fe content } & \multirow{3}{*}{$\begin{array}{l}\text { Particulate Fe at } 0 \mathrm{~m}^{\mathrm{a}} \\
\qquad\left(\mathrm{mg} \mathrm{l}^{-1}\right)\end{array}$} \\
\hline & \multicolumn{2}{|c|}{$\left(\mathrm{nmol} \mathrm{mg} \mathrm{FW}^{-1}\right)$} & \\
\hline & G. skottsbergii & H. grandifolius & \\
\hline Peñón de Pesca & $1.0 \pm 0.5$ & $0.55 \pm 0.05$ & 60 \\
\hline Island D & $2.9 \pm 0.7^{* *}$ & $1.0 \pm 0.2^{*}$ & 850 \\
\hline
\end{tabular}

a Data taken from Abele et al. (2008).

* Significantly different from values obtained in specimens collected from Peñón de Pesca (ANOVA, $\mathrm{p}<0.1$ ).

** Significantly different from values obtained in specimens collected from Peñón de Pesca (ANOVA, $\mathrm{p}<0.05$ ).

species. Gómez et al. (1997) showed that differences in light availability over a vertical profile did not cause changes in Chl- $a$ for most of the studied species. In this study, Chl-a content for G. skottsbergii was significantly higher in specimens isolated from Peñón de Pesca compared to Island D probably due to the stress/impact ratio caused by the strong glacial influence in this area that increase turbidity. On the other hand, Chl- $a$ content in $H$. grandifolius was higher at the site with lower light penetration (Island D), in accordance with previous data from Gómez et al. (1997). Therefore, G. skottsbergii and H. grandifolious showed a species-specific response to light/shade.

In the Island D area, rapid glacial melting may also have incidence on salinity and temperature changes between seasons and years (Schloss et al., 2012). Nevertheless, in this study these variables did not show differences between the Island D and Peñón de Pesca zones during the sampled period, indicating the stability of these physical conditions. Changes in these parameters were shown not to significantly stress the photosynthetic performance of macroalgae (Eggert and Wiencke, 2000; Wiencke and Amsler, 2012). Moreover, among the factors that influence survival and adaptation, oxidative stress conditions could play a major role. The damage/protection indexes studied in this work showed a quite different profile when comparing between samples isolated from different areas. While the $\mathrm{LR} \bullet / \alpha-\mathrm{T}, \mathrm{LR} \bullet / \beta-\mathrm{C}$ and $\mathrm{LR} \bullet /(\alpha-\mathrm{T}+\beta-\mathrm{C})$ content ratios were significantly higher in tissues from $G$. skottsbergii in Island D as compared to those in Peñón de Pesca, the opposite profile was observed in $\mathrm{H}$. grandifolius. These ratios are closely associated with the profile observed in LR content in both G. skottsbergii and $H$. grandifolius samples. The antioxidant capacity, including enzymatic activities and non-enzymatic compounds, followed specific patterns in each species. The enzymatic antioxidant system triggered in the red alga and the consumption of $\mathrm{AH}^{-}$and $\beta-\mathrm{C}$ by the increase in oxidants does not seem sufficiently effective. In contrast, in $H$. grandifolius the enzymatic activity behavior of the GST seems to contribute to reduce the damage in an indirect form (Alves de Almeida et al., 2004) along with the protection afforded by $\mathrm{AH}^{-}$consumption.

The Fe presence in cell membranes is a key feature in the setting of oxidative stress and damage. A characteristic feature of Potter Cove is
Table 5

Activity of enzymatic and content of non-enzymatic antioxidants in $H$. grandifolius.

\begin{tabular}{|c|c|c|c|}
\hline & \multicolumn{2}{|c|}{ Area } & \\
\hline & Peñón de Pesca & Island D & \\
\hline CAT (pmol g FW $\left.{ }^{-1}\right)$ & $1.2 \pm 0.1$ & $0.9 \pm 0.1$ & \\
\hline $\operatorname{SOD}\left(\mathrm{U} \mathrm{g} \mathrm{FW}^{-1}\right)$ & $1540 \pm 90$ & $100 \pm 10^{* *}$ & $(-94 \%)$ \\
\hline $\begin{array}{l}\mathrm{GST} \\
\qquad\left(\mathrm{M} \mathrm{min} \min ^{-1} \mathrm{~g} \mathrm{FW}^{-1}\right)\end{array}$ & $12 \pm 3$ & $20 \pm 5^{*}$ & $(+67 \%)$ \\
\hline $\mathrm{AH}^{-}\left(\mu \mathrm{mol} \mathrm{g} \mathrm{FW}{ }^{-1}\right)$ & $3.23 \pm 0.06$ & $2.98 \pm 0.04^{*}$ & $(-7.7 \%)$ \\
\hline$\alpha-\mathrm{T}\left(\mathrm{nmol} \mathrm{g} \mathrm{FW}^{-1}\right)$ & $2.2 \pm 0.3$ & $2.7 \pm 0.5$ & \\
\hline$\beta-C\left(\mathrm{nmol} \mathrm{g} \mathrm{FW}^{-1}\right)$ & $51 \pm 3$ & $42 \pm 6$ & \\
\hline
\end{tabular}

* Significantly different from values obtained in specimens collected from Peñón de Pesca (ANOVA, $\mathrm{p}<0.05$ )

** Significantly different from values obtained in specimens collected from Peñón de Pesca (ANOVA, $\mathrm{p}<0.001$ ).

that particulate Fe content at 0 m near the glacier in Island D is significantly higher than in Peñón de Pesca (Table 3). The morphology and structure of macroalgae seem to determine Fe uptake capacity, since minerals and trace elements concentrations differ among seaweeds (Astorga-España et al., 2015), also in Antarctica (Farías et al., 2002). Suzuki et al. (1995) reported that in Japanese coastal areas where Fe concentrations were extremely low $(<2 \mathrm{nM})$, the ecosystem was dominated by a red coralline algae (Lithophyllum) while a brown macroalgae was prevented from growing. Since volcanic rocks in King George Island are rich in Fe and sediment ablation expands it in the seawater, the data reported here clearly showed that the higher Fe content in Island D leads to a substantial increase in the Fe content in the macroalgae samples in both specimens. The Fe content in G. skottsbergii algae collected from Peñón de Pesca and in $H$. grandifolius algae inhabiting both Peñón de Pesca and Island D are in the same range $(1.0 \pm 0.5 ; 0.55 \pm$ 0.05 and $1.0 \pm 0.2 \mu \mathrm{mol} \mathrm{g} \mathrm{FW}{ }^{-1}$, respectively). Nonetheless, Fe content in G. skottsbergii tissues from algae collected in Island D is $>3$-fold higher than the rest of the measured values. Moreover, G. skottsbergii total Fe content in Island D was significantly different to that of $H$. grandifolius $(\mathrm{p}<0.01$, ANOVA). These data suggest that even though the intracellular Fe content is influenced by the environment, some mechanisms could be triggered in $H$. grandifolius to avoid a dangerous increase in the total Fe incorporated. Since deleterious effects of Fe are related to its capacity to actively catalyze ROS generation, in agreement with this profile of Fe uptake by the tissues, LR・-dependent EPR signals showed that the LR - content was >3-fold higher in G. skottsbergii inhabiting Island $\mathrm{D}$, as compared to samples isolated from specimens collected in Peñón de Pesca. The LR • content in $H$. grandifolius tissues from macroalgae collected in the Peñón de Pesca zone was in the same range as in G. skottsbergii collected in the same area. The fact that the LR• content in samples isolated from macroalgae collected in Island D showed a significantly lower value than in $H$. grandifolius and $G$. skottsbergii from Peñón de Pesca further suggests a better adaptation in H. grandifolius.

Table 4

Physiological parameters in H. grandifolius.

\begin{tabular}{|c|c|c|}
\hline & \multicolumn{2}{|c|}{ Area } \\
\hline & Peñón de Pesca & Island D \\
\hline $\begin{array}{l}\text { Photosynthetic efficiency }\left(\mu \mathrm{mol} \mathrm{O}_{2} \mathrm{~m}^{2} \mu \mathrm{mol}\right. \\
\text { photons }{ }^{-1} \mathrm{~g} \mathrm{FW}^{-1} \text { ) }\end{array}$ & $0.03 \pm 0.02$ & $0.02 \pm 0.01$ \\
\hline Saturation point ( $\mu \mathrm{mol}$ photons $\mathrm{m}^{-2} \mathrm{~s}^{-1}$ ) & $81 \pm 70$ & $60 \pm 26$ \\
\hline Compensation point ( $\mu \mathrm{mol}$ photons $\mathrm{m}^{-2} \mathrm{~s}^{-1}$ ) & $9 \pm 4$ & $26 \pm 7$ \\
\hline $\mathrm{P}_{\max }\left(\mu \mathrm{mol} \mathrm{O} \mathrm{g} \mathrm{FW}^{-1} \mathrm{~h}^{-1}\right)$ & $44 \pm 14$ & $39 \pm 6$ \\
\hline Respiration $\left(\mu \mathrm{mol} \mathrm{O}_{2} \mathrm{~g} \mathrm{FW}^{-1} \mathrm{~h}^{-1}\right)$ & $-1 \overline{7} \pm 9$ & $-21 \pm 2$ \\
\hline $\begin{array}{l}\text { Daily metabolic carbon balance } \\
\qquad\left(\mathrm{mg} \mathrm{C}^{-1} \mathrm{FW}^{-1} \mathrm{~d}^{-1}\right)\end{array}$ & $0.04 \pm 1.47$ & $-3.9 \pm 0.4^{*}$ \\
\hline Chl- $a$ content $\left(\mu \mathrm{g} \mathrm{FW}^{-1}\right)$ & $283 \pm 15$ & $338 \pm 16^{*}$ \\
\hline
\end{tabular}

* Significantly different from values obtained in specimens collected from Peñón de Pesca (ANOVA, $\mathrm{p}<0.05$ ).

Table 6

Lipid damage and oxidative stress indexes in H. grandifolius.

\begin{tabular}{llll}
\hline & \multicolumn{2}{c}{ Area } \\
\cline { 2 - 3 } & Peñón de Pesca & Island D & \\
\hline $\mathrm{LR} \cdot$ & $256 \pm 17$ & $164 \pm 27^{*}$ & $(-36 \%)$ \\
$\left(\mathrm{nmol} \mathrm{g} \mathrm{FW}{ }^{-1}\right)$ & $116 \pm 5$ & $62 \pm 7^{* *}$ & $(-47 \%)$ \\
$\mathrm{LR} \cdot \alpha-\mathrm{T}$ & $5.3 \pm 0.1$ & $3.9 \pm 0.2^{*}$ & $(-26 \%)$ \\
$\mathrm{LR} \bullet / \beta-\mathrm{C}$ & $5.1 \pm 0.1$ & $3.7 \pm 0.2^{* *}$ & $(-28 \%)$ \\
$\mathrm{LR} \cdot \alpha-\mathrm{T}+\beta-\mathrm{C}$ & & & \\
\hline
\end{tabular}

* Significantly different from values obtained in specimens collected from Peñón de Pesca (ANOVA, $\mathrm{p}<0.05$ ).

** Significantly different from values obtained in specimens collected from Peñón de Pesca (ANOVA, p < 0.01). 


\section{Conclusions}

Our results suggest that the red macroalga G. skottsbergii is more affected than the brown macroalga $H$. grandifolius by the enhancement of an abiotic condition such as the increase of sediment load over the last decades in the studied area. According to Wiencke (1990), G. skottsbergii belongs to seasonal responders who start growing later coinciding with favorable light conditions in spring and summer. The seasonal responder algae react directly to the changing environmental conditions and show an opportunistic life strategy (Wiencke et al., 2007). Although they are adapted to skip rough abiotic conditions $G$. skottsbergii seemed to be more sensitive to the external stress. The Fe present in the seawater was significantly incorporated in G. skottsbergii which may contribute, together with the other physicochemical changes, to the oxidative stress and damage observed in this species. On the other hand, $H$. grandifolius, an Antarctic perennial macroalga, seems to be well adapted to the many physicochemical changes, including the increasing Fe content observed in Island D. The successful adaptation might respond to a wide spectrum of factors and mechanisms, including antioxidant ability to cope with oxidative stress, but further studies are required to have a clear picture of the complex network of factors leading to this successful survival in such an extreme environment.

\section{Contributors}

González P.M., Deregibus D., Malanga G. and Zacher K. participated in the experimental procedures. Campana G.L., Quartino M.L. and Puntarulo S. planned the experiments and analyzed the data. All authors have written, read, approved and contributed to the final version of the manuscript.

\section{Acknowledgments}

We are especially grateful to the scientific and logistic groups of Carlini Station - Dallmann Laboratory for their technical assistance during the Antarctic expeditions. The research was supported by grants from DNA-IAA (PICTA 7/2008-2011) and ANPCyT-DNA (PICTO 0116/ 2012-2015). The present manuscript also presents an outcome of the EU project IMCONet (FP7 IRSES, action no. 319718). This study was also supported by grants from the University of Buenos Aires (20020130100383BA), National Agency of Science and Scientific Promotion (ANPCYT PICT 00845) and National Council for Science and Technology (CONICET PIP 0697). The authors S.P., G.M. and P.M.G. are career investigators from CONICET. [SS]

\section{References}

Abele, D., Atencio, A., Dick, D., Gonzalez, O., Kriews, M., Meyer, S., Philipp, E., Stölting, I., 2008. Iron, copper and manganese discharge from glacial melting into Potter Cove and metal concentrations in Laternula elliptica shells. In: Wiencke, C., Ferreyra, G.A., Abele, D., Marenssi, S. (Eds.), The Antarctic ecosystem of Potter Cove, King-George Island (Isla 25 de Mayo). Bremerhaven, pp. 39-46.

Aebi, H., 1984. Catalase in vitro. Methods Enzymol. 105, 121-126.

Aguilera, J., Bischof, K., Karsten, U., Hanelt, D., Wiencke, C., 2002. Seasonal variation in ecophysiological patterns in macroalgae from an Arctic fjord. II. Pigment accumulation and biochemical defence systems against high light stress. Mar. Biol. 140, 1087-1095.

Ahn, I.-Y., Lee, S.H., Kim, K.T., Shim, J.H., Kim, D.Y., 1996. Baseline heavy metal concentrations in the Antarctic clam, Laternula elliptica in Maxwell Bay, King George Island Antarctica. Mar. Pollut. Bull. 32, 592-598.

Alves de Almeida, E., Miyamoto, S., Celso Dias Bainy, A., Gennari de Medeiros, M.H., Di Mascio, P., 2004. Protective effect of phospholipid hydroperoxide glutathione peroxidase (PHGPX) agaist lipid peroxidation in mussels Perna perna exposed to different metals. Mar. Pollut. Bull. 49, 386-392.

Astorga-España, M.S., Rodríguez Galdón, B., Rodríguez Rodríguez, E.M., Díaz Romero, C., 2015. Mineral and trace element concentrations in seaweeds from the sub-Antarctic ecoregion of Magallanes (Chile). J. Food Compos. Anal. 39, 69-76.

Billard, E., Reyes, J., Mansilla, A., Faugeron, S., Guillemin, M.L., 2015. Deep genetic divergence between austral populations of the red alga Gigartina skottsbergii reveals a cryptic species endemic to the Antarctic continent. Polar Biol. 38, 2021-2034.

Bradford, M.M., 1976. A rapid and sensitive method for the quantitation of microgram quantities of protein utilizing the principle of protein-dye binding. Anal. Biochem. $72,248-254$.
Brumby, P.E., Massey, V., 1967. Determination of nonheme iron, total iron, and copper. Methods Enzymol. 10, 463-472.

Chow, C.K. (Ed.), 1988. Cellular Antioxidant Defense Mechanisms. Vol. I and II. CRC Press, Boca Raton, FL (222 pp).

Collén, J., Pinto, E., Pedersén, M., Colepicolo, P., 2003. Induction of oxidative stress in the red macroalga Gracilaria tenuistipitata by pollutant metals. Arch. Environ. Contam. Toxicol. 45, 337-342.

Deregibus, D., Scharf, F.K., Pasotti, F, Ruiz Barlett, E., Servetto, N., Abele, D., 2015. IMCONet Research Areas Map of Potter Cove, King-George Island (I. 25 de Mayo), With Links to Maps. Buenos Aires, Argentina, Instituto Antártico Argentino http://dx.doi.org/10. 1594/PANGAEA.853859.

Deregibus, D., Quartino, M.L., Campana, G.L., Momo, F.R., Wiencke, C., Zacher, K., 2016. Photosynthetic light requirements and vertical distribution of macroalgae in newly ice-free areas in Potter Cove, South Shetland Islands, Antarctica. Polar Biol. 39 (1), $153-166$.

Di Rienzo, J.A., Casanoves, F., Balzarini, M.G., Gonzalez, L., Tablada, M., Robledo, C.W., 2008. InfoStat versión 2008. Grupo InfoStat. Facultad de Ciencias Agropecuarias, Universidad Nacional de Córdoba, Córdoba, Argentina.

Dierssen, H.M., Smith, R.C., Vernet, M., 2002. Glacial meltwater dynamics in coastal waters west of Antarctic Peninsula. Proc. Natl. Acad. Sci. 99, 1790-1795.

Drew, E.A., 1983. Physiology of Laminaria I. Use of excised lamina discs in short and long term experiments. PSZN I. Mar. Ecol. 4, 211-226.

Drew, E.A., Hastings, R.M., 1992. A year-round ecophysiological study of Himantothallus grandifolius (Desmarestiales, Phaeophyta) at Signy Island, Antarctica. Phycologia 31, 262-277.

Du Laing, G., Tack, F.M.G., Verloo, M.G., 2003. Performance of selected destruction methods for the determination of heavy metals in reed plants (Phragmites australis). Anal. Chim. Acta 497, 191-198.

Eggert, A., Wiencke, C., 2000. Adaptation and acclimation of growth and photosynthesis of five Antarctic red algae to low temperatures. Polar Biol. 23, 609-618.

Eraso, A., Domínguez, M.A., 2007. Physicochemical characteristics of the subglacier discharge in Potter Cove, King George Island, Antarctica. In: Tyk, A., Stefaniak, K. (Eds.), Karst and Cryokarst, Studies of the Faculty of Earth Sciences. University of Silesia Vol. 45, pp. 111-122.

Evstigneeva, R.P., Volkov, I.M., Chudinova, V.V., 1998. Vitamin E as a universal antioxidant and stabilizer of biological membranes. Membr. Cell Biol. 12, 151-172.

Fairhead, V.A., Amsler, C.D., McClintock, J.B., Baker, B.J., 2005. Variation in phlorotannin content within two species of brown macroalgae (Desmarestia anceps and $D$. menziesii) from the Western Antarctic Peninsula. Polar Biol. 28, 680-686.

Farías, S.P.A., Vodopivez, C., Smichowski, P., 2002. Levels of essential and potentially toxic trace metals in Antarctic macroalgae. Spectrochim. Acta Part B At. Spectrosc. 57, 2133-2140.

Gómez, I., Weykam, G., Kloser, H., Wiencke, C. 1997. Photosynthetic light requirements, metabolic carbon balance and zonation of sublittoral macroalgae from King George Island (Antarctica). Mar. Ecol. Prog. Ser. 148, 281-293.

González, P.M., Aguiar, M.B., Malanga, G., Puntarulo, S., 2013. Electronic paramagnetic resonance (EPR) for the study of ascorbyl radical and lipid radicals in marine organisms. Comp. Biochem. Physiol. A Physiol. 165, 439-447.

Gutt, J., Bertler, N., Bracegirdle, T.J., Buschmann, A., Comiso, J., Hosie, G., Isla, E., Schloss, I.R., Smith, C.R., Tournadre, J., Xavier, J.C., 2015. The Southern Ocean ecosystem under multiple climate stresses - an integrated circumpolar assessment. Glob. Chang. Biol. 21, 1434-1453.

Habig, W.H., Pabst, M.J., Jakobi, W.B., 1974. Glutathione-S-transferases: the first enzymatic step in mercapturic acid formation. J. Biol. Chem. 249, 7130-7139.

Halliwell, B., Gutteridge, J.M.C., 1989. Oxygen is poisonous - an introduction to oxygen toxicity and free radicals. In: Halliwell, B., Gutteridge, J.M.C. (Eds.), Free Radicals in Biology and Medicine. Oxford University Press, London, pp. 1-21.

Hommersand, M.H., Moe, R.L., Amsler, C.D., Fredericq, S., 2009. Notes on the systematics and biogeographical relationships of Antarctic and sub-Antarctic Rhodophyta with descriptions of four new genera and five new species. Bot. Mar. 52, 509-534.

Inskeep, W.P., Bloom, P.R., 1985. Extinction coefficients of chlorophyll $a$ and b in $N, N-$ dimethylformamide and 80\% acetone. Plant Physiol. 77, 483-485.

Jurkiewicz, B.A., Buettner, G.R., 1994. Ultraviolet light-induced free radical formation in skin: an electron paramagnetic resonance study. Photochem. Photobiol. 59, 1-4.

Kirst, G.O., Wiencke, C., 1995. Ecophysiology of polar algae. J. Phycol. 31, 181-199.

Kotake, Y., Tanigawa, T., Tanigawa, M., Ueno, I., Randel Allen, D., Lai, C.-S., 1996. Continuous monitoring of cellular nitric oxide generation by spin trapping with an iron-dithiocarbamate complex. Biochim. Biophys. Acta 1289, 362-368.

Kutnink, M.A., Hawkes, W.C., Schaus, E.E., Omaye, S.T., 1987. An internal standard method for the unattended high-performance liquid chromatographic analysis of ascorbic acid in blood components. Anal. Biochem. 166, 424-430.

Li, Y., Qian, A.J., Ryu, B., Lee, S.H., Kim, M.M., Kim, S.K., 2009. Chemical components and its antioxidant properties in vitro: An edible marine brown alga, Ecklonia cava. Bioorg. Med. Chem. 17, 1963-1974.

Malanga, G., Puntarulo, S., 1995. Oxidative stress and antioxidant content in Chlorella vulgaris after exposure to ultraviolet-B radiation. Physiol. Plant. 94, 672-679.

McCord, J.M., Fridovich, I., 1969. Superoxide dismutase: an enzymatic function for erythrocuprein (hemocuprein). J. Biol. Chem. 244, 6049-6055.

Quartino, M.L., Deregibus, D., Campana, G.L., Latorre, G.E.J., Momo, F.R., 2013. Evidence of macroalgal colonization on newly ice-free areas following glacial retreat in Potter Cove (South Shetland Islands), Antarctica. PLoS One 8 (3), e58223. http://dx.doi. org/10.1371/journal.pone.0058223.

Rückamp, M., Braun, M., Suckro, S., Blindow, N., 2011. Observed glacial changes on the King George Island ice cap, Antarctica, in the last decade. Glob. Plan. Chang. 79, 99-109. 
Sahade, R., Lagger, C., Torre, L., Momo, F., Monien, P., Schloss, I., Barnes, D.K.A., Servetto, N. Tarantelli, S., Tatián, M., Zamboni, N., Abele, D., 2015. Climate change and glacier retreat drive shifts in an Antarctic benthic ecosystem. Sci. Adv. 1 (10). http://dx.doi.org/ 10.1126/sciadv. 1500050 .

Schloss, I.R., Abele, D., Moreau, S., Demers, S., Bers, A.V., González, O., Ferreyra, G.A., 2012. Response of phytoplankton dynamics to 19 year (1991-2009) climate trends in Potter Cove (Antarctica). J. Mar. Syst. 92, 53-66.

Suzuki, Y., Kuma, K., Kudo, I., Matsunaga, K., 1995. Iron requirement of the brown macroalgae Laminaria japonica, Undaria pinnatifida (Phaeophyta) and the crustose coralline alga Lithophyllum yessoense (Rhodophyta), and their competition in the northern Japan Sea. Phycologia 34 (3), 201-205.

Tatur, A., Valle, R., Barczuk, A., 1999. Discussion on the Uniform Pattern of Holocene Tephro Chronology in South Shetland Islands, Antarctica. Polish Polar Studies, Proceedings of XXVI Polar Symposium pp. 305-321.
Templeton, D.M., Liu, Y., 2003. Genetic regulation of cell function in response to iron overload or chelation. Biochim. Biophys. Acta 1619 (2), 113-124.

Wiencke, C., 1990. Seasonality of red and green macroalgae from Antarctica-a long-term culture study under fluctuating Antarctic daylengths. Polar Biol. 10, 601-607.

Wiencke, C., Amsler, C.D., 2012. Seaweeds and their communities in polar regions. In: Wiencke, C., Bischof, K. (Eds.), Seaweed Biology, Novel Insights into Ecophysiology, Ecology and UtilizationEcological Studies Vol. 219. Springer, Heidelberg, pp. 265-292

Wiencke, C., Clayton, M.N., 2002. Antarctic seaweeds. In: Wägele, J.W. (Ed.), Synopsis of the Antarctic Benthos 9. A.R.G. Ganter Verlag KG, Ruggell. 1, Switzerland, p. 239.

Wiencke, C., Clayton, M.N., Gómez, I., Iken, K., Lüder, U.H., Amsler, C.D., Karsten, U., Hanelt, D., Bischof, K., Dunton, K., 2007. Life strategy, ecophysiology and ecology of seaweeds in polar waters. Rev. Environ. Sci. Biotechnol. 6, 95-126. 